\title{
Disrupted Prediction Error Links Excessive Amygdala Activation to Excessive Fear
}

\author{
Auntora Sengupta, ${ }^{1}$ Bryony Winters, ${ }^{2}$ Elena E. Bagley, ${ }^{2}$ and Gavan P. McNally ${ }^{1}$ \\ ${ }^{1}$ School of Psychology, University of New South Wales Australia, Sydney, New South Wales 2052, Australia, and ${ }^{2}$ Discipline of Pharmacology, University of \\ Sydney, Sydney, New South Wales 2006, Australia
}

Basolateral amygdala (BLA) is critical for fear learning, and its heightened activation is widely thought to underpin a variety of anxiety disorders. Here we used chemogenetic techniques in rats to study the consequences of heightened BLA activation for fear learning and memory, and to specifically identify a mechanism linking increased activity of BLA glutamatergic neurons to aberrant fear. We expressed the excitatory hM3Dq DREADD in rat BLA glutamatergic neurons and showed that CNO acted selectively to increase their activity, depolarizing these neurons and increasing their firing rates. This chemogenetic excitation of BLA glutamatergic neurons had no effect on the acquisition of simple fear learning, regardless of whether this learning led to a weak or strong fear memory. However, in an associative blocking task, chemogenetic excitation of BLA glutamatergic neurons yielded significant learning to a blocked conditioned stimulus, which otherwise should not have been learned about. Moreover, in an overexpectation task, chemogenetic manipulation of BLA glutamatergic neurons prevented use of negative prediction error to reduce fear learning, leading to significant impairments in fear inhibition. These effects were not attributable to the chemogenetic manipulation enhancing arousal, increasing asymptotic levels of fear learning or fear memory consolidation. Instead, chemogenetic excitation of BLA glutamatergic neurons disrupted use of prediction error to regulate fear learning.

Key words: amygdala; anxiety; DREADD; extinction; fear conditioning; prediction error

\section{Significance Statement}

Several neuropsychiatric disorders are characterized by heightened activation of the amygdala. This heightened activation has been hypothesized to underlie increased emotional reactivity, fear over generalization, and deficits in fear inhibition. Yet the mechanisms linking heightened amygdala activation to heightened emotional learning are elusive. Here we combined chemogenetic excitation of rat basolateral amygdala glutamatergic neurons with a variety of behavioral approaches to show that, although simple fear learning is unaffected, the use of prediction error to regulate this learning is profoundly disrupted, leading to formation of inappropriate fear associations and impaired fear inhibition.

\section{Introduction}

Pavlovian fear conditioning enables learning about, and adaptive responding to, sources of danger in the world. The amygdala is critical for the formation, consolidation, and retrieval of fear memories (Davis, 1992; Schafe et al., 2001; Maren and Quirk,

\footnotetext{
Received Oct. 4, 2015; revised Nov. 5, 2015; accepted Nov. 13, 2015.

Author contributions: A.S., B.W., E.E.B., and G.P.M. designed research; A.S. and B.W. performed research; A.S., B.W., E.E.B., and G.P.M. analyzed data; A.S., B.W., E.E.B., and G.P.M. wrote the paper.

A.S. was supported by an Australian Postgraduate Award. G.P.M. was supported by a Future Fellowship from Australian Research Council FT120100250. This work was supported by Australian Research Council Grant FT120100250 to G.P.M. and National Health and Medical Research Council Grants 1077806 to G.P.M. and E.E.B. and 1047372 to E.E.B. and G.P.M. We thank Pascal Carrive and Adam Hamlin for advice on CaMKII $\alpha$ immunohistochemistry; and Nathan Marchant, Rick Richardson, Fred Westbrook, and Nathan Holmes for discussions of these experiments.

The authors declare no competing financial interests.

Correspondence should be addressed to Dr. Gavan P. McNally, School of Psychology, University of New South Wales Australia, Sydney, NSW 2052, Australia. E-mail: g.mcnally@unsw.edu.au.

DOI:10.1523/JNEUROSCI.3670-15.2016

Copyright $\odot 2016$ the authors $\quad 0270-6474 / 16 / 360385-11 \$ 15.00 / 0$
}

2004; Paré et al., 2004; Lüthi and Lüscher, 2014). Principal cells of the basolateral amygdala (BLA) receive glutamatergic inputs from thalamus and cortex conveying information about the conditioned stimulus (CS) and aversive footshock unconditioned stimulus (US) (Farb and Ledoux, 1999; Shi and Davis, 1999; Sah et al., 2003; Lanuza et al., 2008), and their activity is sufficient for fear learning (Johansen et al., 2010a). These glutamatergic neurons are subject to complex regulation by multiple families of GABAergic interneurons (Ehrlich et al., 2009; Wolff et al., 2014; Tovote et al., 2015), show synaptic plasticity during fear conditioning, and form fear memories in an NMDA receptordependent manner (McKernan and Shinnick-Gallagher, 1997; Maren and Quirk, 2004; Marek et al., 2013).

The amygdala has also long been implicated in normal and clinical human anxiety and fear. Several neuropsychiatric disorders are characterized by heightened activation of the amygdale; and in the case of anxiety, such heightened activation is widely thought to underpin clinical aberrations in fear (Rauch et al., 
2006; Jovanovic and Ressler, 2010; Shin and Liberzon, 2010). For example, in human neuroimaging studies, sufferers of clinical anxiety, including simple phobia (Goossens et al., 2007), posttraumatic stress (Shin et al., 1997, 2005), and social anxiety (Tillfors et al., 2001, 2002), show heightened amygdala activation during fear provocation or during failures of fear inhibition (Rauch et al., 2006; Jovanovic and Ressler, 2010). Such heightened amygdala activation has also been linked to augmented fear responding in nonhuman animal studies (Desmedt et al., 2015).

However, the mechanisms linking excessive amygdala activation to excessive fear learning and fear responding remain elusive. Here we used chemogenetic excitation of rat BLA glutamatergic neurons (Armbruster et al., 2007; Alexander et al., 2009; Urban and Roth, 2013; Sternson and Roth, 2014) to identify the consequences of heightened amygdala glutamatergic neuronal activity for BLA neurons, fear learning, and fear memory formation. We show that, although simple fear learning is unaffected by chemogenetic excitation of BLA glutamatergic neurons, the use of prediction error to regulate this fear learning is profoundly disrupted, leading to formation of inappropriate fear associations and impaired learning of fear inhibition.

\section{Materials and Methods}

\section{Subjects}

A total of 153 experimentally naive male Sprague Dawley rats (260-350 g) were obtained from Animal Resources Centre (Murdoch, Western Australia). Animals were housed in groups of four maximum in ventilated racks in a climate-controlled colony room. The colony room was maintained on a $12 \mathrm{~h} \mathrm{light/dark} \mathrm{cycle} \mathrm{(lights} \mathrm{on} \mathrm{at} \mathrm{7:00} \mathrm{A.M.).} \mathrm{Three} \mathrm{days}$ before commencement of experimental procedures, rats were food restricted to $85 \%-90 \%$ of their free feeding weight. Otherwise, rats had free access to food and water. The University of New South Wales Animal Care and Ethics Committee and the University of Sydney Animal Ethics Committee approved the procedures.

\section{Apparatus}

All behavioral procedures were conducted in eight identical operant chambers with dimensions 24 (length) $\times 30$ (width) $\times 21 \mathrm{~cm}$ (height). The top, rear wall and hinged door of the chambers were constructed of Perspex. The sidewalls of the chambers were constructed of stainless steel panels. All chambers had a grid floor constructed of stainless steel rods, 4 $\mathrm{mm}$ in diameter spaced $15 \mathrm{~mm}$ apart. The grid floor was connected to a constant current generator. A magazine (entry space $5 \times 5 \mathrm{~cm}$ ) was built in to the left side panel and was attached to a pellet delivery system that delivered $45 \mathrm{~g}$ grain pellets (Able Scientific Biotechnology). A lever was mounted $4 \mathrm{~cm}$ to the right of the magazine hopper. Each chamber was placed in a larger sound-attenuating box, dimensions 83 (length) $\times 59$ (width) $\times 59 \mathrm{~cm}$ (height). A fan was attached to the right side wall to provide sufficient ventilation during behavioral testing. Two CS were used. The auditory CS was a $60 \mathrm{~s} 80 \mathrm{~dB}$ clicker delivered through a speaker attached to the right side of the rear wall of the operant chamber and the visual CS was a $60 \mathrm{~s}$ flashing LED $(8$ [length] $\times 5$ [width] $\times 3 \mathrm{~cm}$ [height]) mounted on the ceiling of the sound attenuating chamber. The US was a scrambled footshock delivered to the grid floor and was $0.5 \mathrm{~s}$ in duration. The intensity of the US depended on the behavioral procedure used. All behavioral protocols were controlled through Med-PC software (Med Associates).

\section{Viral vectors}

Adeno-associated viral (AAV) vectors encoding the hM3Dq DREADD or eYFP were obtained from the University of North Carolina Vector Core (Chapel Hill, NC). The vectors used in these experiments were AAV5-

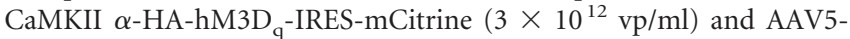
CaMKII $\alpha$-eYFP $\left(4 \times 10^{12} \mathrm{vp} / \mathrm{ml}\right)$.

\section{Surgery}

Before surgery, rats received an intraperitoneal injection of a mixture of $100 \mathrm{mg} / \mathrm{ml}$ ketamine (Ketapex, Apex Laboratories) and $0.3 \mathrm{ml} / \mathrm{kg}$ xyla- zine (Rompun; Bayer). Once anesthetized, rats were placed in a stereotaxic apparatus (model 942, Kopf) and shaved to expose the skin surface of the head. Before incision, rats received a subcutaneous injection of carprofen $(5 \mathrm{mg} / \mathrm{kg})$ and an injection of $0.5 \%$ bupivacaine (Cenvet) just under the surface of the incision site. Following incision, a hand drill was used to make two craniotomies above the BLA and a $5 \mu \mathrm{l}$, 30-gauge conical tipped microinfusion syringe (Hamilton) was used to infuse 0.75 $\mu l$ of AAV vectors into BLA (anteroposterior -3.00 ; mediolateral \pm 5.00 ; dorsoventral -8.60 in $\mathrm{mm}$ from bregma) (Paxinos and Watson, 2007) over a $3 \mathrm{~min}$ period at a rate of $0.25 \mu \mathrm{l} / \mathrm{min}$ (UMP3 with SYS4 Microcontroller; World Precision Instruments). The syringe was left in place for 5-7 min to permit diffusion of the injected vectors. Bone wax (Coherent Scientific) was used to seal the opening of the skull. After surgery, rats were injected intraperitoneally with $0.3 \mathrm{ml}$ of $300 \mathrm{mg} / \mathrm{ml}$ solution of procaine penicillin (Benicillin; Illium) and subcutaneously with $0.3 \mathrm{ml}$ of a $100 \mathrm{mg} / \mathrm{ml}$ solution of cephazolin (Hospira). Daily postoperative and recovery procedures, including weight and infection management, were conducted for the remainder of the experiment. All behavioral procedures commenced a minimum of 3 weeks after surgery.

Experiment 1: chemogenetic activation of BLA glutamatergic neurons We validated $\mathrm{hM} 3 \mathrm{Dq}$ expression in BLA CaMKII $\alpha$-positive cells and confirmed BLA cellular response to clozapine- $n$-oxide (CNO; RTI International). After a minimum of 3 weeks after surgery, rats were killed for immunohistochemical detection of mCitrine and CaMKII $\alpha(n=4)$. For c-Fos and mCitrine immunohistochemistry, all rats had been infused

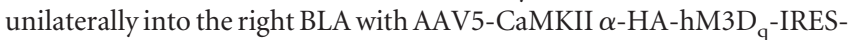
mCitrine so that the nontransduced hemisphere could serve as a withinsubjects control. These rats received an intraperitoneal injection of 3 $\mathrm{mg} / \mathrm{kg} \mathrm{CNO}$ (diluted in $5 \%$ DMSO and saline; $n=6)$ or vehicle $(n=6)$ 3 weeks following surgery and then killed with an intraperitoneal injection of sodium pentobarbital 150 min later.

Acute slices were prepared from both unilaterally and bilaterally injected animals at least 6 weeks following viral injections (rats aged 15-17 weeks). Rats were anesthetized with isoflurane, decapitated, and their brains were quickly removed and chilled in ice-cold cutting solution (in $\mathrm{mm}$ ) as follows: $125 \mathrm{NaCl}, 25 \mathrm{NaHCO}_{3}, 11$ D-glucose, $2.5 \mathrm{KCl}, 1.25$ $\mathrm{NaH}_{2} \mathrm{PO}_{4} .2 \mathrm{H}_{2} \mathrm{O}, 2.5 \mathrm{MgCl}_{2}$, and $0.5 \mathrm{CaCl}_{2}$, saturated with carbogen $\left(95 \% \mathrm{O}_{2} / 5 \% \mathrm{CO}_{2}\right)$. Coronal slices $(280 \mu \mathrm{m})$ containing the amygdala were cut using a V1200S vibratome (Leica). Slices were hemisected and initially incubated in an NMDG-HEPES recovery solution (in $\mathrm{mM}$ ) as follows: $93 \mathrm{NMDG}$ chloride, $2.5 \mathrm{KCl}, 1.2 \mathrm{NaH}_{2} \mathrm{PO}_{4}, 30 \mathrm{NaHCO}_{3}, 20$ HEPES, $25 \mathrm{D}$-glucose, 5 sodium ascorbate, 2 thiourea, 3 sodium pyruvate, $10 \mathrm{MgCl}_{2}, 0.5 \mathrm{CaCl}_{2}, \mathrm{pH} 7.3,300-310 \mathrm{mOsm} / \mathrm{L}$, heated to $34^{\circ} \mathrm{C}$ and saturated with carbogen for $10 \mathrm{~min}$ (Zhao et al., 2011). Slices were then returned to carbogenated cutting solution and incubated for a further 20 $\mathrm{min}$ at $34^{\circ} \mathrm{C}$, then allowed to equilibrate to room temperature for at least $30 \mathrm{~min}$.

For recording, slices were transferred to the recording chamber and continually perfused $(\sim 2 \mathrm{ml} / \mathrm{min})$ with aCSF containing (in $\mathrm{mm}$ ) the following: $125 \mathrm{NaCl}, 25 \mathrm{NaHCO}_{3}, 11 \mathrm{D}$ - glucose, $2.5 \mathrm{KCl}, 1.25$ $\mathrm{NaH}_{2} \mathrm{PO}_{4} \cdot 2 \mathrm{H}_{2} \mathrm{O}, 1 \mathrm{MgCl}_{2}$, and $2 \mathrm{CaCl}_{2}$, saturated with carbogen and heated to $32^{\circ} \mathrm{C}-34^{\circ} \mathrm{C}$. In all cases, NBQX ( $5 \mu \mathrm{M}$, Abcam Biochemicals) and picrotoxin (100 $\mu \mathrm{M}$, Sigma) were included in the circulating aCSF to block fast excitatory and inhibitory transmission respectively. $\mathrm{hM}_{3} \mathrm{D}_{\mathrm{q}}$ transfected BLA neurons were readily identified using an Olympus BX51 microscope equipped with $40 \times$ water-immersion objective, Dodt gradient contrast optics, and epifluorescence illumination. Whole-cell current-clamp recordings were made from both mCitrine $^{+}$and mCitrine ${ }^{-}$BLA neurons using patch pipettes $(3-5 \mathrm{M} \Omega)$ containing the following (in $\mathrm{mm}$ ): 135 potassium gluconate, $8 \mathrm{NaCl}, 0.5 \mathrm{EGTA}, 10$ HEPES, 2 Mg-ATP, 0.3 Na-GTP, and 0.1\% biocytin, pH 7.3, 280-285 $\mathrm{mOsm} / \mathrm{L}$. Because of high levels of $\mathrm{hM} 3 \mathrm{D}_{\mathrm{q}}$ expression in the BLA that received AAV injections, recordings from mCitrine $^{-}$BLA neurons were performed on slices from noninjected hemispheres of unilaterally injected animals. To monitor changes in membrane voltage, continuous chart recordings were made from cells held in current-clamp mode with zero current injected. To elicit minimal firing, a $1 \mathrm{~s}$ depolarizing current pulse (typically $100-300 \mathrm{pA}$ ) was applied every 10 s. Following CNO 
application, mCitrine ${ }^{+}$cells were held up to $1 \mathrm{~h}$ to monitor drug washout, whereas mCitrine ${ }^{-}$cells were allowed $10 \mathrm{~min}$ washout before the application of the broad-spectrum muscarinic agonist carbachol $(10 \mu \mathrm{M}$ for $5 \mathrm{~min}$; Sigma). Recordings were performed using a MultiClamp 700B amplifier (Molecular Devices), filtered at $5 \mathrm{kHz}$, and sampled at $10 \mathrm{kHz}$. Data were acquired and analyzed using Axograph software (Molecular Devices). Series resistance was monitored throughout each experiment, and data were discarded if this fluctuated $>20 \%$ or if series resistance was $>20 \mathrm{M} \Omega$.

\section{Experiment 2: chemogenetic activation of BLA glutamatergic} neurons and fear learning

In these experiments, as per our previous work (Arico and McNally, 2014; Yau and McNally, 2015), we used conditioned suppression of lever pressing for food to assess Pavlovian-conditioned fear. Conditioned suppression as a measure of fear has several advantages for the study of fear prediction errors. It has a nonzero baseline because rats lever press for a pellet reward at a constant rate and so can reveal decreases and increases in fear; there are relatively high levels of baseline activity during training and testing sessions; it is equally sensitive to visual and auditory CS despite these CS eliciting different amounts of freezing; each of the seminal behavioral preparations identifying the actions of prediction error on fear association formation was established using conditioned suppression; and, finally, assessment of conditioned suppression is completely automated.

Baseline lever pressing. Rats were trained to lever press to establish a stable baseline lever pressing response. On days 1 and 2, rats received magazine training in which every lever press was rewarded with the delivery of a pellet. In addition, rats also received free pellet deliveries on a fixed interval $300 \mathrm{~s}$ schedule, in which a pellet was delivered on average every $300 \mathrm{~s}$. Magazine training sessions were terminated after $60 \mathrm{~min}$ or if the rat reached 100 lever presses. If rats failed to reach 100 lever presses, they were shaped to lever press by the experimenter. On day 3 , rats underwent a 60 min session of lever press training under a variable interval (VI) $30 \mathrm{~s}$ schedule. From day 4 until the end of the experiment, rats were maintained on a VI $120 \mathrm{~s}$ schedule of lever pressing. These sessions lasted 120 min unless otherwise noted. On days 9 and 10, rats received preexposure to a visual CS (flashing LED). This CS was presented four times for $60 \mathrm{~s}$, inter-trial interval (ITI) ranging from 1200 to $1800 \mathrm{~s}$.

Acquisition. Rats were randomly allocated to a weak US group or a strong US group. All rats underwent fear conditioning on days 11 and 12 . Rats received four $60 \mathrm{~s}$ presentations of the visual CS with a randomized ITI of 1200-1800 s while being maintained on a VI 120 s. These presentations coterminated with a $0.5 \mathrm{~s}, 0.6 \mathrm{~mA}$ US for the strong US groups or a $0.5 \mathrm{~s}, 0.3 \mathrm{~mA}$ US for the weak US groups. These sessions lasted $120 \mathrm{~min}$. Thirty minutes before these sessions, rats were injected intraperitoneally with $\mathrm{CNO}(3 \mathrm{mg} / \mathrm{kg})$ or vehicle.

Extinction test. Rats were tested across days 13-16. Rats received four $60 \mathrm{~s}$ presentations of CSA alone with an ITI of $900 \mathrm{~s}$ while being maintained on a VI 120 s schedule. Each test session lasted 70 min.

\section{Experiment 3: chemogenetic activation of BLA glutamatergic} neurons prevents use of prediction error to regulate fear learning Baseline lever pressing. The procedures used for baseline lever press training were as described previously. On days 9 and 10, rats received preexposure to CSA (flashing LED) and CSB (clicker). CS were presented for $60 \mathrm{~s}$, four times each with ITIs ranging from 1200 to $1800 \mathrm{~s}$.

Stage I. Rats were randomly allocated to groups Block and Control. On days 11-13, groups Block received four $60 \mathrm{~s}$ presentations of CSA with a randomized ITI of 1200-1800 s while being maintained on a VI $120 \mathrm{~s}$ lever pressing schedule. Each CSA presentation coterminated with a $0.5 \mathrm{~s}$ footshock US (0.8 mA). Each Stage I session lasted for $120 \mathrm{~min}$. Rats in groups Control received further VI 120 training.

Stage II. On days 14 and 15, all rats received four $60 \mathrm{~s}$ presentations of a compound comprising CSA and CSB (CSAB) with a randomized ITI of $490-1200 \mathrm{~s}$ while being maintained on a VI 120 s lever pressing schedule. The compound CSAB coterminated with a $0.5 \mathrm{~s}$ US $(0.8 \mathrm{~mA})$. These sessions lasted $70 \mathrm{~min}$ each. Thirty minutes before the commencement of each session rats received intraperitoneal injection of either $\mathrm{CNO}$ (3 $\mathrm{mg} / \mathrm{kg}$ ) or vehicle.
Test. All rats were tested on day 16. Rats received four $60 \mathrm{~s}$ presentations of CSB with an ITI of $900 \mathrm{~s}$ while being maintained on a VI $120 \mathrm{~s}$ lever pressing schedule. This session lasted $70 \mathrm{~min}$.

\section{Experiment 4: chemogenetic activation of BLA glutamatergic} neurons prevents use of negative prediction error to reduce fear Baseline lever pressing. The procedures used for baseline lever press training and CS preexposure (days 1-10) were the same as described previously with one exception. All procedures in this experiment were conducted with the house light on.

Stage I. Rats underwent Stage I training on days 11-13. They received two $60 \mathrm{~s}$ presentations of CSA and two $60 \mathrm{~s}$ presentations of CSB with a randomized ITI of 1200-1800 s while being maintained on a VI $120 \mathrm{~s}$ schedule. Each stimulus was reinforced with a $0.5 \mathrm{~s}, 0.8 \mathrm{~mA}$ US. The order of CS presentations was counterbalanced. Each Stage I session lasted 120 min.

Stage II. Rats underwent Stage II training on days 14-16. Rats were randomly allocated to groups Over and groups Control. Rats in groups Over received four $60 \mathrm{~s}$ presentations of a CSAB compound with a randomized ITI of 490-1200 s while being maintained on a VI $120 \mathrm{~s}$ schedule. Each compound presentation coterminated with a $0.5 \mathrm{~s}, 0.8 \mathrm{~mA}$ US. Each Stage II session lasted $70 \mathrm{~min}$. Rats in groups Control received further VI $120 \mathrm{~s}$ lever press training without any CS or US presentations. Thirty minutes before each Stage II session, rats received an intraperitoneal injection of CNO $(3 \mathrm{mg} / \mathrm{kg})$ or vehicle.

Test. All rats were tested for both CSA and CSB in two separate test sessions on days 17 and 18 . These sessions were counterbalanced for CS identity. Rats received four 60 s presentations of CSA and CSB alone with an ITI of $900 \mathrm{~s}$ between presentations. Each session lasted for $70 \mathrm{~min}$.

\section{Immunohistochemistry}

Following transcardial perfusion with $0.9 \%$ saline, $1 \%$ sodium nitrite solution, and $360 \mu \mathrm{l} / \mathrm{L}$ heparin, then $4 \%$ buffered PFA, brains were postfixed and then placed in $20 \%$ hypertonic sucrose solution for $24-48 \mathrm{~h}$. A cryostat (Leica Microsystems) was used to collect $40 \mu \mathrm{m}$ coronal sections, preserved in phosphate buffered azide $(0.1 \%$ sodium azide $)$ at $4^{\circ} \mathrm{C}$ before immunohistochemistry.

Immunoreactivity for mCitrine (AAV5-CaMKII $\alpha$-HA-hM3D $\mathrm{q}^{-}$ IRES-mCitrine) and eYFP (AAV5- CaMKII $\alpha$-eYFP) was performed (chicken anti-eGFP; Invitrogen; A10262). CaMKII $\alpha$ and eGFP immunoreactivity (IR) were processed using two-color immunofluorescence. Free-floating sections were washed for $20 \mathrm{~min}$ in $0.1 \mathrm{M}$ phosphate buffer (PB; pH 7.4), followed by 5 min in PB Triton X (PBTx; 0.2\%; pH 7.4), then treated with sodium citrate buffer, $\mathrm{pH} 6.0$, at $75^{\circ} \mathrm{C}$ for $15 \mathrm{~min}$ and 10 min off heat. Sections were washed with PBTx (10 min), blocked ( $2 \mathrm{~h}, 5 \%$ NGS in PBTx), and then placed in 1:500 rabbit anti-CaMKII $\alpha$ (Abcam; ab92332) and 1:750 chicken anti-GFP (Invitrogen; A10262, diluted in a solution of $0.2 \%$ PBTx and $2 \%$ NGS) at $4^{\circ} \mathrm{C}$ for $48 \mathrm{~h}$. Sections were washed in $\mathrm{PB}$ for $30 \mathrm{~min}$ and then incubated in 1:500 Alexa-555 goat anti-rabbit (Invitrogen; A21429) and 1:750 Alexa-488 goat anti-chicken (Invitrogen; A11039), diluted in PBTx $(0.2 \%)$ and $2 \%$ NGS at room temperature for $3 \mathrm{~h}$. Sections were washed for $30 \mathrm{~min}$ in $\mathrm{PB}$, mounted, and coverslipped (Permfluor, Thermo Scientific). CaMKII $\alpha$-IR and eGFP-IR used a confocal microscope (Olympus BX61) and Fluoview FV1200 software.

c-Fos-IR and eGFP IR were processed using two-color peroxidase immunohistochemistry. Free-floating sections were washed for $30 \mathrm{~min}$ in $0.1 \mathrm{~m}$ phosphate buffer (PB; pH 7.4), followed by $50 \%$ ethanol (EtOH) for $30 \mathrm{~min}$ and then $3 \%$ hydrogen peroxide diluted in $50 \% \mathrm{EtOH}$ for 30 min. Sections were blocked (30 min with 5\% NHS diluted in PB), then placed in 1:1000 rabbit anti-c-fos (Santa Cruz Biotechnology; sc-52) and 1:2000 chicken anti-GFP (Invitrogen; A10262) diluted in 0.3\% Triton-X, $2 \% \mathrm{NHS}$, and $0.1 \mathrm{M} \mathrm{PB}, \mathrm{pH} 7.4$, and incubated at $4^{\circ} \mathrm{C}$ for $48 \mathrm{~h}$. Sections were washed three times for 20 min each (PB, pH 7.4), incubated in 1:3000 biotinylated donkey anti-rabbit (Jackson ImmunoResearch Laboratories; $711,065,152$ ) (diluted in a solution of $0.3 \%$ Triton-X, $2 \%$ NHS, and $0.1 \mathrm{M} \mathrm{PB}, \mathrm{pH} 7.4$ ), overnight at room temperature. They were then washed in $\mathrm{PB}, \mathrm{pH} 7.4$, and incubated in Avidin-Biotin (ABC reagent; Vector Elite kit $6 \mu \mathrm{l} / \mathrm{ml}$ avidin and $6 \mu \mathrm{l} / \mathrm{ml}$ biotin) diluted with $\mathrm{PB}$ 
containing $0.2 \%$ Triton, $\mathrm{pH}$ 7.4. c-Fos IR was identified using a nickel intensified DAB (D5637-56, Sigma) reaction. Immediately before this, sections were washed twice in $\mathrm{PB}, \mathrm{pH}$ 7.4, and once in $0.1 \mathrm{~m}$ acetate buffer, $\mathrm{pH}$ 6.0. Sections were incubated in $\mathrm{DAB}$ solution (0.025\% DAB, $0.04 \%$ ammonium chloride, and $0.2 \% \mathrm{D}$-glucose in $0.1 \mathrm{M}$ acetate buffer, $\mathrm{pH}$ 6.0 ). The peroxidase reaction was catalyzed by $0.2 \mu \mathrm{l} / \mathrm{ml}$ glucose oxidase and then rinsed with $0.1 \mathrm{M}$ acetate buffer. Sections were then washed with $\mathrm{PB}$ and incubated in biotinylated donkey anti-chicken (1:3000; Jackson ImmunoResearch Laboratories; 703, 065, 155) overnight before a second $\mathrm{DAB}$ reaction, without nickel intensification, to identify brown eGFP-IR cells. Sections were then washed thoroughly with $\mathrm{PB}$ and mounted, dehydrated, cleared, and coverslipped (Entellan, ProSciTech). cFos-IR and eGFP-IR were imaged at $20 \times$ using a transmitted light microscope (Olympus BX51) and counted using Photoshop (Adobe).

\section{Data analysis}

Suppression ratios were calculated as $S R=a /(a$ $+b)$ (Annau and Kamin, 1961), where $a$ represents the number of lever presses during the $\mathrm{CS}$ period and $b$ represents the number of lever presses recorded $60 \mathrm{~s}$ pre CS. A SR of 0.5 indicates low suppression or low fear, whereas an SR of 0 indicates complete suppression or high fear. For the acquisition experiment, data from each trial of acquisition and the first trial on each day of test were analyzed. For the blocking experiment, the first trial each day was reported and analyzed. For overexpectation, the first trial for each day of Stages I and II and trials across both test days (CSA and CSB) were analyzed. Behavioral data and c-Fos-IR neuronal counts were analyzed via planned contrasts (Harris, 2004). The Hay's Decision-wise error rate $(\alpha)$ was controlled at 0.05 for each contrast.

\section{Results}

Experiment 1: chemogenetic activation of BLA glutamatergic neurons

First, we used AAV5-CaMKII $\alpha$-HA$\mathrm{hM} 3 \mathrm{D}(\mathrm{Gq})$-IRES-mCitrine (hereafter referred to as hM3Dq) to express the designer muscarinic receptor bilaterally in rat BLA glutamatergic neurons $(n=4)$, and we quantified immunoreactivity (IR) for CaMKII $\alpha$ and mCitrine/eGFP in BLA to confirm expression in this cell type (Fig. $1 A)$. There were significantly more dual CaMKII $\alpha$-IR/eGFP-IR cells than single eGFP-IR cells $\left(F_{(1,3)}=19.35, p<0.05\right)$, and almost all eGFP-IR cells were localized to CaMKII $\alpha$-IR cells (Fig. $1 B$ ).

Then we used detection of the activity marker c-Fos to determine the effects of chemogenetic excitation of BLA glutamatergic neurons. Rats $(n=12)$ with expression of $\mathrm{hM} 3 \mathrm{D}_{\mathrm{q}}$ in the right BLA received intraperitoneal injection of either $\mathrm{CNO}(3 \mathrm{mg} / \mathrm{kg})$ or vehicle before examination of c-Fos expression in the right (transduced) and left (nontransduced) BLA. CNO $(n=6)$ caused significant recruitment of BLA neurons (Fig. 1C) relative to in-
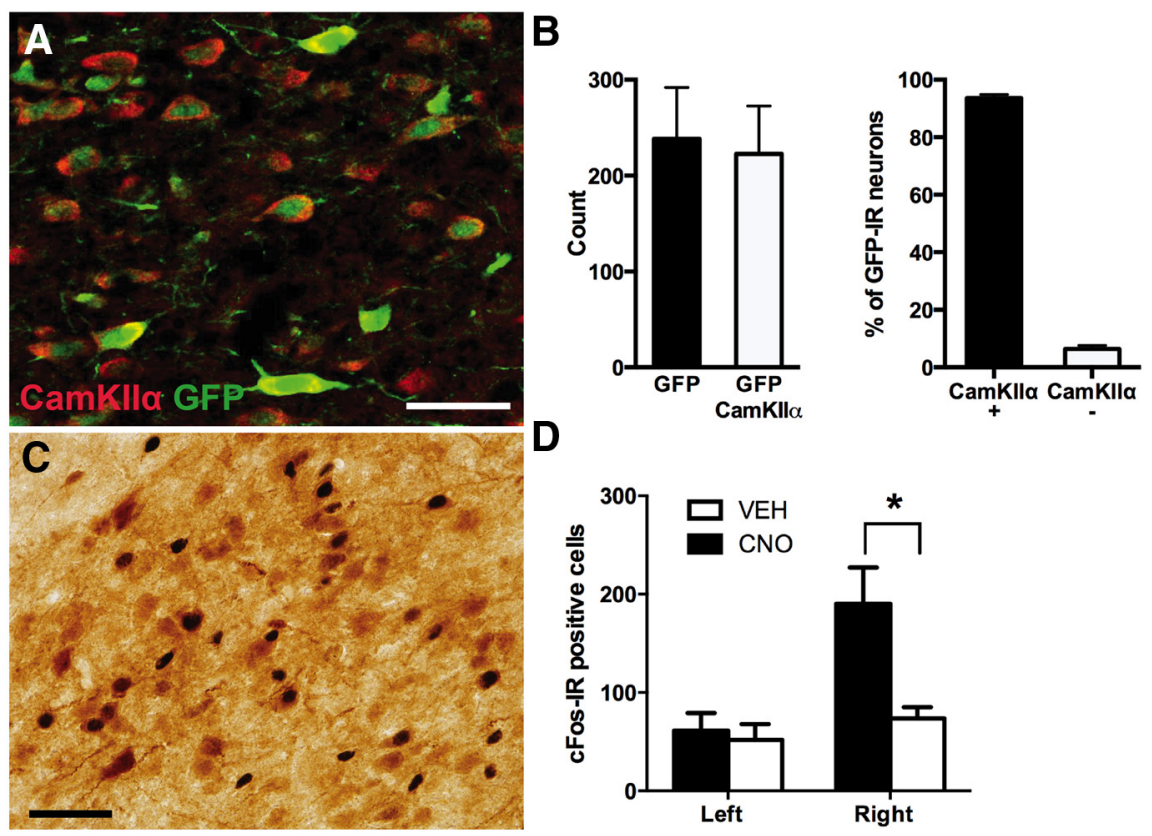

D
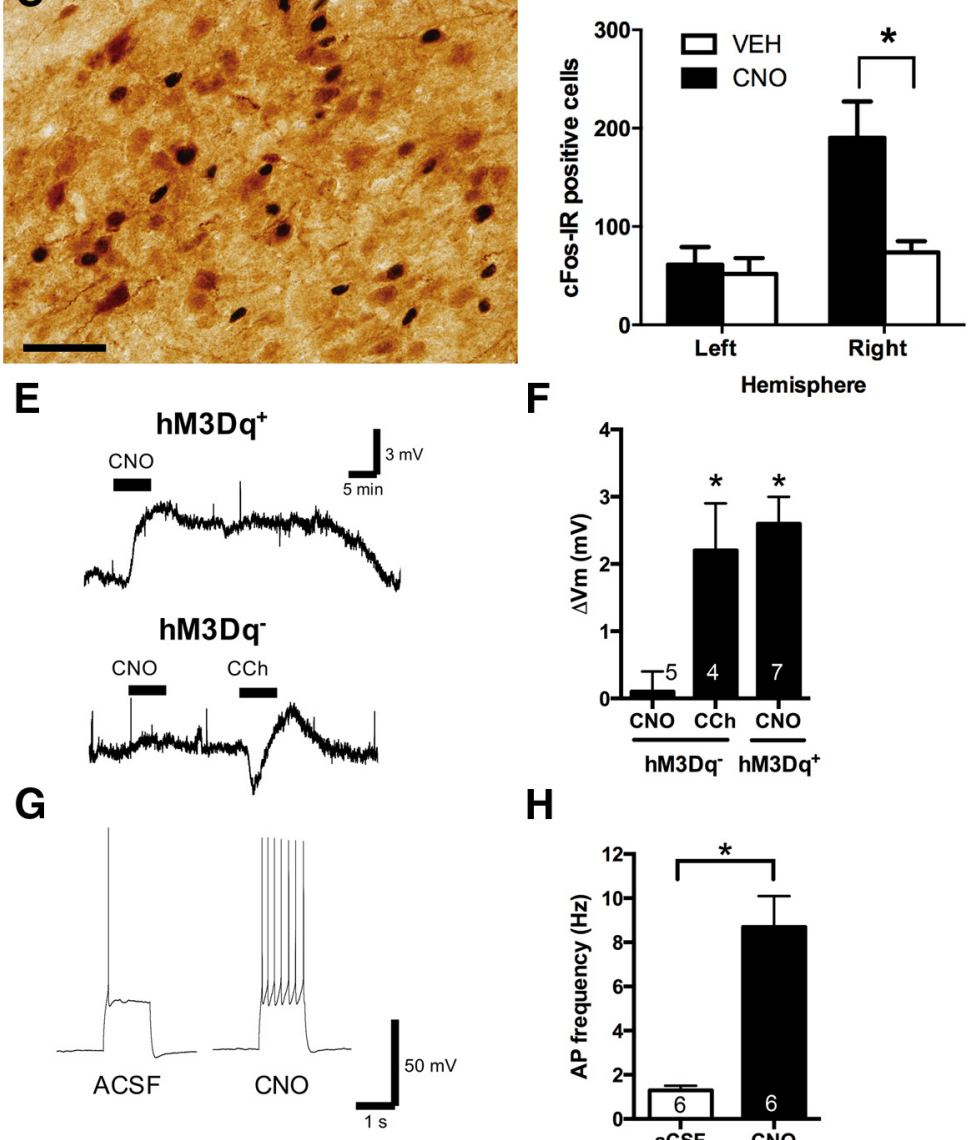

$\mathbf{F}$

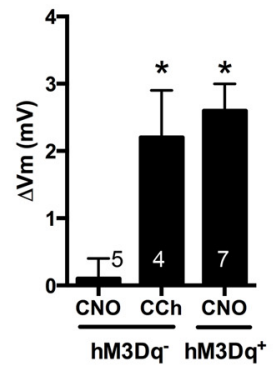

H

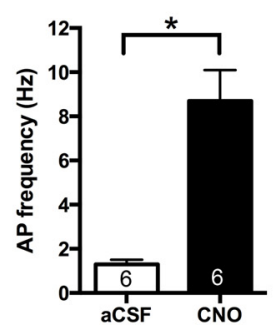

Figure 1. Chemogenetic activation of BLA glutamatergic neurons. $A$, Colocalization of CaMKII $\alpha-I R$ and DREADD ${ }^{+}$(eGFP-IR) BLA cells (red represents CaMKII $\alpha$-IR; green represents eGFP-IR). Scale bar, $25 \mu \mathrm{m}$. B, Total eGFP-IR and eGFP-IR/CaMKII $\alpha$-IR dual-labeled cells in rat BLA and percentage of CaMKII $\alpha{ }^{+}$and CaMKII $\alpha{ }^{-}$eGFP-IR cells. ${ }^{*} p<0.05$. Group size: CaMKII $\alpha$ - hM3D ${ }_{q^{\prime}}$ $n=4$. C, Representative c-Fos-IR (black) and eGFP-IR (brown) cells in an hM3D animal injected with CNO ( $3 \mathrm{mg} / \mathrm{kg}$, i.p.) Scale bar, $50 \mu \mathrm{m}$. D, Total c-Fos-IR in transduced (right) and nontransduced (left) BLA. ${ }^{*} p<0.05$ (hemisphere $\times$ drug interaction). Group

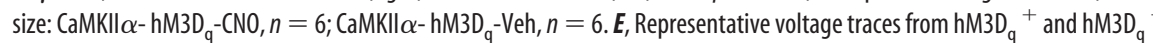
BLA neurons. $\boldsymbol{F}, \mathrm{CNO}(1-5 \mu \mathrm{M})$ depolarized $\mathrm{hM} \mathrm{Dq}^{+} / \mathrm{mCitrine}^{+}$neurons but had no effect on $\mathrm{hM3Dq}{ }^{-} / \mathrm{mCitrine}^{-}$neurons, which remained responsive to carbachol. ${ }^{*} p<0.05$. G, Representative voltage response from $\mathrm{hM3Dq}{ }^{+} / \mathrm{mCitrine}^{+}$neurons to minimal depolarizing current injection (100-300 pA, 1s) before (aCSF) and during CNO (5 $\mu \mathrm{M})$ application. $\boldsymbol{H}$, CNO significantly increased action potential (AP) frequency in $\mathrm{hM} 3 \mathrm{Dq}^{+} / \mathrm{mCitrine}^{+}$neurons. ${ }^{*} p<0.05$. Data are mean $\pm \mathrm{SEM}$; the number of neurons per experiment is indicated at the corresponding bars. Group size: $\mathrm{CaMKII} \alpha-\mathrm{hM} 3 \mathrm{D}_{\mathrm{q}^{\prime}}, n=7$.

jection of vehicle $(n=6)$ (main effect: $\left.F_{(1,10)}=11.34, p<0.05\right)$, and this increase in $\mathrm{c}$-Fos expression was selective to the right BLA (interaction: $\left.F_{(1,10)}=6.18, p<0.05\right)$ (Fig. $1 D$ ).

Next, we made whole-cell current-clamp recordings from $\mathrm{hM} 3 \mathrm{Dq}^{+} \mathrm{BLA}$ neurons to determine the effects of $\mathrm{hM} 3 \mathrm{D}_{\mathrm{q}}$ receptor activation on neuronal activity. Bath application of CNO (1-5 $\mu \mathrm{M})$ for 5 min significantly depolarized $\mathrm{hM} \mathrm{Dq}^{+}$BLA neurons by $2.6 \pm 0.3 \mathrm{mV}$ compared with baseline membrane potentials 


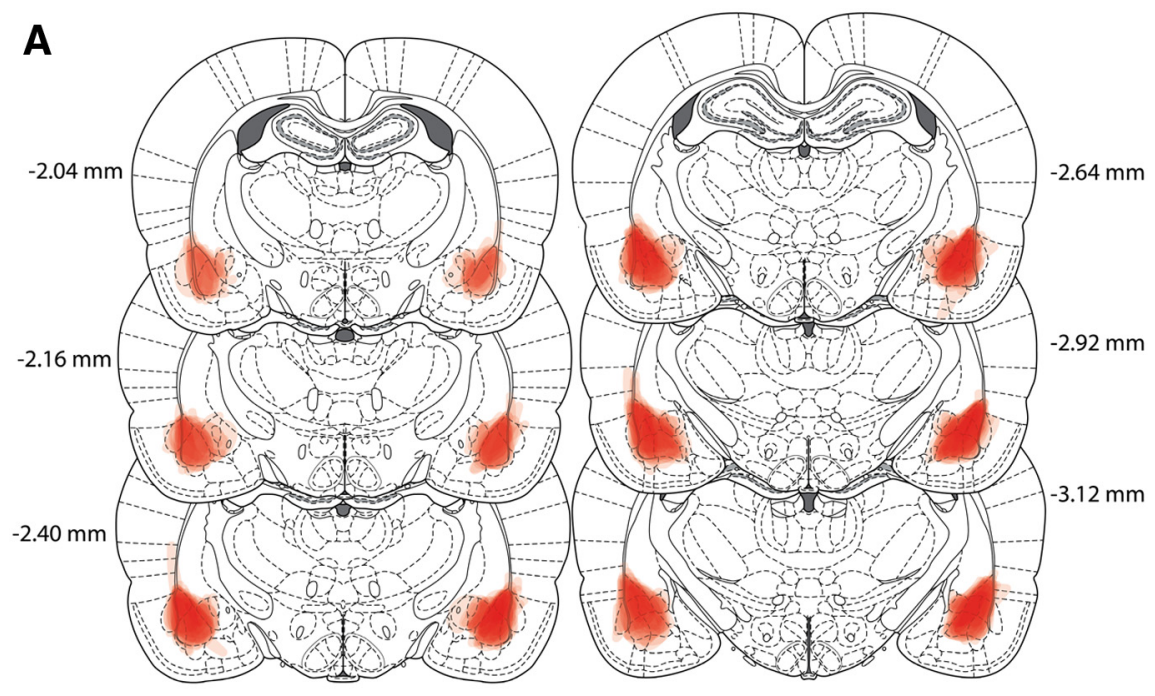

B
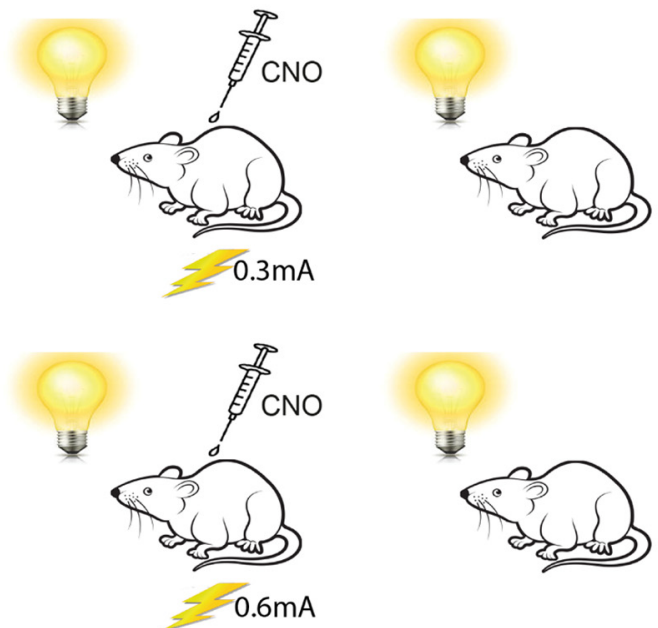

C

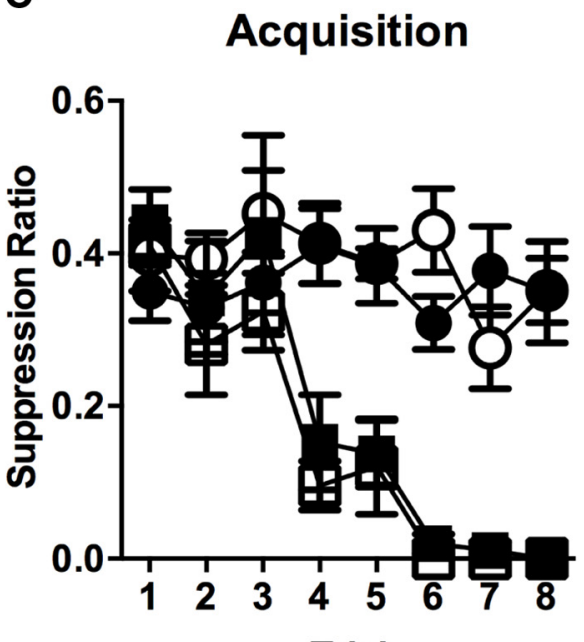

Trial

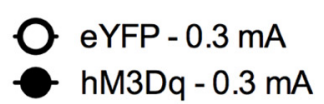

Test
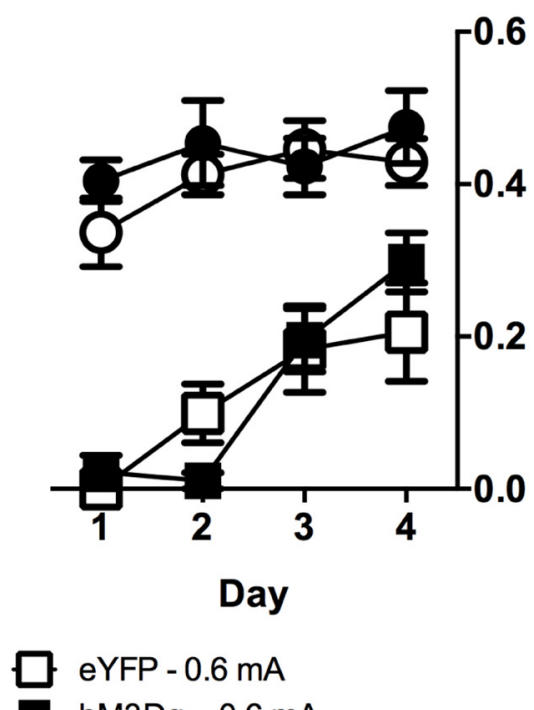

$\mathrm{hM} 3 \mathrm{Dq}-0.6 \mathrm{~mA}$

Figure 2. Chemogenetic activation of BLA glutamatergic neurons and fear learning. $\boldsymbol{A}$, Extent of eGFP-IR for each rat included in the analysis represented at $10 \%$ opacity. $B$, Behavioral procedure. Groups $0.3 \mathrm{~mA}$ received visual $\mathrm{CS}-0.3 \mathrm{~mA}$ shock training and the Groups $0.6 \mathrm{~mA}$ received visual CS- $0.6 \mathrm{~mA}$ training during acquisition. CNO ( $3 \mathrm{mg} / \mathrm{kg}$, i.p.) was injected $30 \mathrm{~min}$ before acquisition

(paired $t$ test, $p<0.05 ; n=7$; Fig. $1 E, F$ ). This depolarization was sufficient to markedly increase firing rate (Fig. $1 G$ ) compared with baseline firing evoked by a $1 \mathrm{~s}$ depolarizing current injection (100$300 \mathrm{pA})$ that elicited minimal firing (paired $t$ test, $p<0.05, n=6$; Fig. $1 H)$. In contrast, no significant change in membrane potential was observed for $\mathrm{hM}_{3} \mathrm{Dq}^{-}$BLA neurons from the nontransduced hemisphere (paired $t$ test, $p>$ 0.05; $n=5$; Fig. $1 E, F)$. Importantly, we found no deficit in endogenous muscarinic receptor activity in these $\mathrm{hM} 3 \mathrm{Dq}^{-}$cells because the broad-spectrum muscarinic agonist carbachol $(10 \mu \mathrm{M})$ induced an initial hyperpolarization followed by a marked depolarization in $\mathrm{hM}^{2} \mathrm{Dq}^{-}$BLA neurons (paired $t$ test, $p<0.01 ; n=4$, Fig. $1 E, F$ ). This biphasic response is consistent with changes in conductance of various ion channels following broad-spectrum muscarinic activation (McQuiston and Madison, 1999; Bell et al., 2013). Hence, $\mathrm{CNO}$ selectively depolarizes and increases the firing rate of $\mathrm{hM} 3 \mathrm{D}_{\mathrm{q}}$ expressing BLA neurons while not affecting nonexpressing neurons.

Experiment 2: chemogenetic activation of BLA glutamatergic neurons and fear learning

We then asked whether this chemogenetic excitation of BLA glutamatergic neurons yields heightened fear learning and memory formation. Rats with bilateral BLA expression of hM3Dq $(n=22)$ or AAV5CaMKII $\alpha$-eYFP (hereafter referred to as eYFP) $(n=18)$ (Fig. $2 A)$ were trained to fear a visual CS via pairings with a $0.3 \mathrm{~mA}$ (weak) or $0.6 \mathrm{~mA}$ (strong) footshock to establish weak or strong fear memories, respectively (Fig. 2B). They were injected with CNO $30 \mathrm{~min}$ before these training sessions. Rats were later tested for their fear responses (conditioned suppression) to the visual CS in the absence of CNO.

\section{Histology}

Figure $2 A$ shows the extent of eGFP-IR across all rats included in the analyses with each rat represented at $10 \%$ opacity.

\section{$\leftarrow$}

training. C, Mean \pm SEM suppression ratios are shown for acquisition and test. A ratio of $0.5=$ no suppression of lever pressing during the $C S$ (no fear), and $0=$ complete suppression of lever pressing during the $C S$ (high fear). The $0.6 \mathrm{~mA}$ footshock conditioned more fear than $0.3 \mathrm{~mA}(p<0.05)$, but there was no effect of chemogenetic excitation $(p>$ 0.05). Group sizes: CaMKII $\alpha$-hM3 $\mathrm{D}_{\mathrm{q}}-0.6 \mathrm{~mA}, n=5$; CaMKII $\alpha$-eYFP-0.6 mA, $n=7$; CaMKII $\alpha$-hM3D $\mathrm{q}_{\mathrm{q}}-0.3 \mathrm{~mA}$, $n=7$; CaMKII $\alpha$-eYFP- $0.3 \mathrm{~mA}, n=9$. 
A

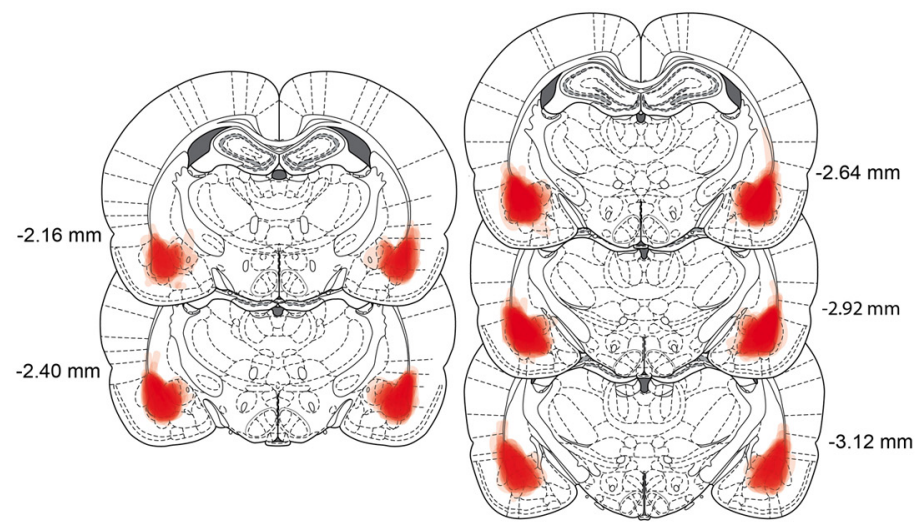

B

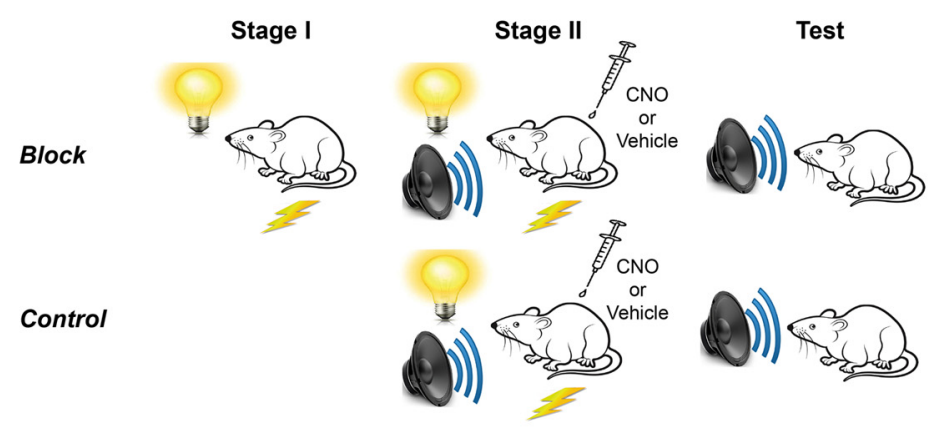

C

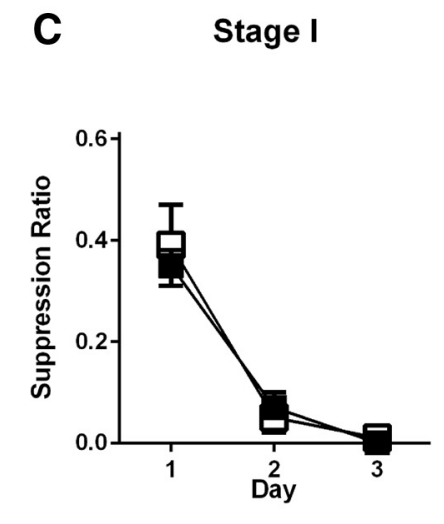

Stage II
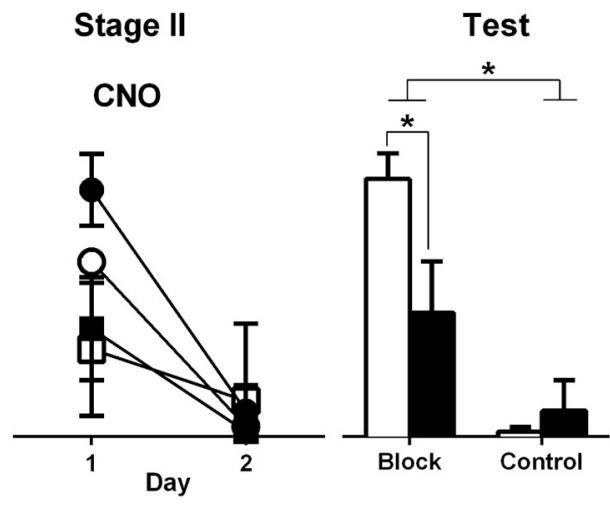

Block - hM3Dq

Block-eYFP

Control-hM3Da

Control-eYFP
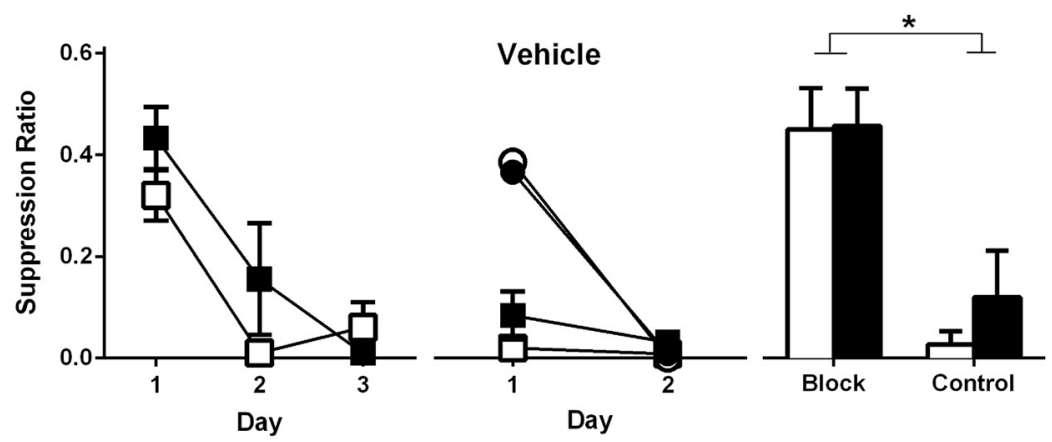

Figure 3. Chemogenetic activation of BLA glutamatergic neurons prevents use of prediction error to regulate fear learning. $\boldsymbol{A}$, Extent of eGFP-IR for each rat included in the analysis represented at $10 \%$ opacity. $B$, Behavioral procedure. Groups Block received Stage I CSA-shock training. In Stage II, all groups received CSAB-shock pairings. CNO (3 mg/kg, i.p.) or Vehicle (i.p.) was injected 30 min before Stage Il sessions. All rats were then tested for fear to CSB.C, Mean \pm SEM suppression ratios during Stage I, Stage II, and test for CNO (top) or vehicle (bottom). There was evidence for blocking in CaMKII $\alpha$-eYFP-Veh and CaMKII-hM3D ${ }_{\mathrm{q}}$-Veh and CaMKII $\alpha$-hM3D -CNO-Misplaced groups, versus CaMKII-hM3D $D_{q}$-Veh. Blocking was attenuated in CaMKII $\alpha$-hM3D $\mathrm{D}_{\mathrm{q}}$-CNO versus CaMKII $\alpha$-eYFP-CNO. ${ }^{*} p<0.05$. Group sizes: CaMKII $\alpha$-hM3D - -Block-CNO, $n=5$; CaMKII $\alpha$-hM3D ${ }_{q}$-Control-CNO, $n=6$;
Twelve rats were excluded due to expression of the eYFP or hM3Dq being located predominantly outside the BLA.

\section{Behavior}

The $0.6 \mathrm{~mA}$ footshock supported more fear learning than the $0.3 \mathrm{~mA}$ footshock across training (Fig. $2 C)\left(F_{(1,24)}=48.15\right.$, $p<0.05)$ and test $\left(F_{(1,24)}=149.88, p<\right.$ $0.05)$, confirming that the different shock intensities used during training established weak and strong fear memories. $\mathrm{CNO}$ was injected before acquisition training only. However, chemogenetic excitation of BLA glutamatergic neurons had no effect on this fear learning and memory formation, assessed across the course of CS-US pairings or during the subsequent extinction tests (all $F_{(1,24)}<1$, $p>0.05)$, regardless of whether such memories were weak or strong. So, chemogenetic excitation was not able to convert weak fear learning into stronger learning, was unable to shift asymptotic levels of fear learning, and did not augment fear memory consolidation.

Experiment 3: chemogenetic activation of BLA glutamatergic neurons prevents use of prediction error to regulate fear learning

The failure of chemogenetic excitation to affect simple fear learning and memory formation shows that the consequences of heightened BLA glutamatergic neuronal activation for fear learning and memory are subtle. A key feature of normal fear learning and amygdala synaptic plasticity is that they are tightly regulated by prediction error (McNally and Westbrook, 2006; McNally et al., 2011). In this way, only mismatches between predicted and actual danger (i.e., prediction errors) trigger fear learning (Rescorla and Wagner, 1972).

To examine the impact of chemogenetic excitation of BLA glutamatergic neurons on use of fear prediction errors, rats expressing hM3Dq $(n=28)$ or eYFP $(n=28)$ bilaterally in BLA (Fig. $3 A$ ) were assessed in an associative blocking procedure (Kamin, 1968) (Fig. 3B) with injections of CNO $30 \mathrm{~min}$ before Stage II. In this task, rats were first trained that CSA (visual CS) predicts footshock. Subse-
CaMKII $\alpha$-eYFP-Block-CNO, $n=7$; CaMKII $\alpha$-eYFP-ControlCNO, $n=5$; CaMKII $\alpha$-hM3D -Block-Vehicle, $n=5$; CaMKII $\alpha$ hM3D ${ }_{\mathrm{q}}$-Control-Vehicle, $n=6$; CaMKII $\alpha$-eYFP-Block-Vehicle, $n=7$; CaMKII $\alpha$-eYFP-Control-Vehicle, $n=7$; CaMKII $\alpha$ hM3D ${ }_{\mathrm{q}}$-CNO-Misplaced, $n=6$. 
quently, CSA was presented in compound with a neutral CSB (auditory CS) and followed by the same footshock. The prior fear learning to CSA blocks learned fear to CSB. This occurs because the animal's expectations are matched to the danger posed, generating minimal prediction error and minimal fear learning. A control group, on the other hand, receiving just Stage II training of a neutral CSA presented in compound with a neutral CSB and followed by footshock, does learn fear to CSB. This occurs due to positive prediction error. If chemogenetic excitation of BLA glutamatergic neurons disrupts this regulation of fear learning by prediction error, then it will cause inappropriate fear learning to the blocked CSB.

\section{Histology}

Figure $3 A$ shows the extent of eGFP-IR across all rats included in the analyses with each rat represented at $10 \%$ opacity. Eight animals were excluded due to misplaced hM3Dq or eYFP expression, primarily in the surrounding CeA or endopiriform cortex or unilaterally in BLA.

\section{Behavior}

All block groups acquired fear across Stage I (main effect of day: $\left.F_{(1,20)}=80.11, p<0.05\right)$ (Fig. 3C), and there were no differences between groups $\left(\mathrm{hM} 3 \mathrm{D}_{\mathrm{q}}\right.$ vs eYFP; $F_{(1,20)}<1, p>0.05$; CNO vs Veh; $F_{(1,20)}<1, p>0.05$; interactions: $\left.F_{(1,20)}<1, p>0.05\right)$.

During Stage II, the block groups expressed fear to the compound CSAB (main effect Block vs Control: $F_{(1,36)}=12.27, p<$ 0.05 ), whereas the control groups acquired fear (main effect of day: $F_{(1,36)}=71.92, p<0.05$; group $\times$ day interaction: $F_{(1,36)}=$ 25.53, $p<0.05$ ). There was no effect of DREADD (main effect: $\left.F_{(1,36)}<1, p>0.05\right)$, CNO injection $\left(F_{(1,36)}=2.9, p>0.05\right)$, or interaction (group $\times$ drug $\times$ DREADD interaction: $F_{(1,36)}<1$, $p>0.05)$. Further simple effect analyses showed no differences between the DREADD and eYFP groups during Stage II. So, there was no effect of the DREADD on fear expression during Stage II (all $p<0.05$ ).

The results from test revealed normal use of prediction error to regulate learning among the vehicle groups. Animals that received vehicle injections during Stage II demonstrated associative blocking (i.e., less fear to CSB in Block than Control groups, main effect: $F_{(1,21)}=23.25, p<0.05$ ) regardless of the DREADD (main effect: $F_{(1,21)}<1, p>0.05$; group $\times$ DREADD interaction: $F_{(1,21)}$ $<1, p>0.05$ ). So, there was fear learning to the CS signaling an unexpected footshock (positive prediction error) and no fear learning to the CS signaling an expected footshock (no prediction error).

In contrast, chemogenetic activation of BLA glutamatergic neurons prevented this use of prediction error to guide fear learning (main effect of DREADD: $F_{(1,19)}=5.22, p<0.05$; group $\times$ DREADD interaction $\left.F_{(1,19)}=4.43, p<0.05\right)$. Associative blocking was attenuated in $\mathrm{hM} 3 \mathrm{D}_{\mathrm{q}}$ animals $\left(\mathrm{CNO}-\mathrm{hM} 3 \mathrm{D}_{\mathrm{q}}\right.$ Block vs CNO-eYFP-Block: $\left.F_{(1,19)}=9.96, p<0.05\right)$, causing inappropriate fear learning to the blocked CS in $\mathrm{hM}_{3} \mathrm{D}_{\mathrm{q}}$ animals. This inappropriate fear learning was selective to the associative blocking manipulation because chemogenetic excitation had no effect on fear learning in the Control groups $\left(F_{(1,19)}<1, p>0.05\right)$.

To verify that this DREADD-driven disruption of prediction error was anatomically specific to BLA, we examined animals treated with CNO that had robust but misplaced expression of $\mathrm{hM} 3 \mathrm{D}_{\mathrm{q}}$. This misplaced expression was typically in central nucleus of the amygdala or piriform cortex (Fig. $3 \mathrm{C}$; CNO-hM3 $\mathrm{D}_{\mathrm{q}-}$ Block-Misplaced, $n=6$ ). In contrast to animals with BLA hM3Dq expression, these animals with misplaced hM3Dq ex- pression showed normal use of prediction error. Associative blocking was intact yielding no fear learning to expected danger (vs CNO-Block-eYFP group: $F_{(1,15)}<1, p>0.05$; vs CNOhM3 $\mathrm{D}_{\mathrm{q}-}$ Block group: $\left.F_{(1,15)}=5.29, p<0.05\right)$. This confirms the anatomical selectivity of disrupted prediction error by BLA chemogenetic manipulation.

\section{Experiment 4: chemogenetic activation of BLA glutamatergic neurons prevents use of negative prediction error to inhibit fear}

Finally, we asked whether this failure of prediction error to regulate learning extends to the inhibition of fear. Fear inhibition is profoundly disrupted in anxiety disorders, and such disruption is associated with hyperactivity of the amygdala (Rachman, 1994; Guthrie and Bryant, 2006; Michael et al., 2007; Jovanovic et al., 2010, 2012; Dunsmoor and Paz, 2015). In rodents, such fear inhibition is often studied via extinction. However, deficits in extinction learning have numerous causes that do not necessarily reflect deficits in use of negative prediction error (Storsve et al., 2010, 2012).

We used an overexpectation procedure (Rescorla, 1970; Lattal and Nakajima, 1998; McNally et al., 2004; Rescorla, 2007) to specifically isolate negative prediction error causing fear inhibition. Rats expressing hM3D $(n=19)$ or eYFP bilaterally in BLA $(n=15)$ (Fig. $4 A)$ were trained in an overexpectation procedure (Fig. $4 B$ ) so that in Stage I two CS, CSA (visual) and CSB (auditory), separately predicted footshock. In Stage II, the two cues were presented in compound and followed by the same footshock for the overexpectation group. This causes a reduction in learned fear to both CS. This reduction occurs, despite the footshock US being present, because the animal's expectations of danger have been increased: it sums predictions from both CS to predict two footshocks, but it receives only one. This generates a negative prediction error causing fear inhibition. If chemogenetic activation of BLA glutamatergic neurons disrupts use of negative prediction error to inhibit fear, then CNO injections before Stage II training should prevent overexpectation of fear.

\section{Histology}

Figure $4 A$ shows the extent of eGFP-IR across all rats included in the analyses with each rat represented at $10 \%$ opacity. Seven rats were excluded as per exclusion criteria outlined previously. Two of these animals were in the hM3Dq-Over group.

\section{Behavior}

All groups learned to fear CSA and CSB across Stage I (main effect of day: $F_{(1,23)}=743.51, p<0.05$; no main effect of group: $F_{(1,23)}$ $=1.45, p>0.05$; no interaction: $\left.F_{(1.23)}<1, p>0.05\right)$ (Fig. $4 C$ ). During Stage II, both the eYFP and hM3Dq groups were identical: expressing high levels of fear (no main effect of DREADD: $F_{(1,13)}<1, p>0.05$; no main effect of day: $F_{(1,13)}<1, p>0.05$; no day $\times$ group interaction: $\left.F_{(1,13)}<1, p>0.05\right)$.

Overexpectation caused inhibitory learning and loss of fear (Fig. $4 C$ ) (main effect of group: $F_{(1,23)}=17.71, p<0.05$; no main effect of DREADD: $\left.F_{(1,23)}=2.05, p>0.05\right)$. Importantly, chemogenetic activation of BLA glutamatergic neurons prevented this use of negative prediction error to reduce fear, yielding a significant impairment in learned fear inhibition (group $\times$ DREADD interaction: $F_{(1,23)}=4.50, p<0.05$; hM3 $\mathrm{D}_{\mathrm{q}}$-Over vs eYFPOver: $F_{(1,23)}=6.95, p<0.05 ; \mathrm{hM}^{2} \mathrm{D}_{\mathrm{q}}$-Control vs eYFP-Control: $\left.F_{(1,23)}<1, p>0.05\right)$. 


\section{Discussion}

We used chemogenetic excitation of BLA glutamatergic neurons to identify the mechanisms linking heightened amygdala activation to excessive fear. First, we validated our DREADD approach via immunohistochemistry to show that the

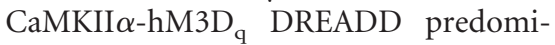
nantly colocalized to BLA CaMKII $\alpha$-IR cells. We then demonstrated that injections of $\mathrm{CNO}$ caused c-Fos expression in the transduced but not nontransduced BLA. Finally, we showed that CNO significantly depolarized $\mathrm{hM}_{3} \mathrm{Dq}^{+}$BLA neurons and markedly increased firing rates evoked by current injection. Next, we used this chemogenetic approach to determine the effects of BLA activation on the acquisition of fear. Chemogenetic excitation of BLA glutamatergic neurons did not augment simple fear learning regardless of whether this learning led to a weak or strong fear memory. Instead, chemogenetic excitation of these neurons acted selectively to prevent the associative blocking of fear learning and also acted to prevent inhibitory fear learning in an overexpectation task.

\section{Methodological considerations}

There was no evidence here that these effects of chemogenetic manipulation on fear learning were due to AAV-mediated expression of the hM3Dq DREADD disrupting general BLA function and/or behavior. In slices, the hM3Dq DREADD caused expected membrane depolarization and increased firing rates. As in our previous work (Yau and McNally, 2015), hM3Dq and eYFP animals acquired the baseline lever pressing task at the same rate and to the same level; they also acquired, retained, and expressed fear at the same levels as the eYFP groups. The $\mathrm{hM} 3 \mathrm{Dq}$ groups were largely indistinguishable from eYFP controls. These findings argue strongly against a nonselective effect of BLA hM3Dq expression on learning or memory.

There was also no evidence that $\mathrm{CNO}$ had nonspecific effects that confound interpretation (Rogan and Roth, 2011), at least in the measures we assessed. In BLA slices, there was no detectable effect of $\mathrm{CNO}$ on membrane potentials in $\mathrm{hM} 3 \mathrm{Dq}^{-}$neurons, despite these neurons showing intact sensitivity to the broadspectrum muscarinic agonist carbachol. At the behavioral level, there was no effect of CNO injection on simple fear learning or memory; and in the associative blocking as well as overexpectation experiments, there was no difference between groups until the test phases. In addition, in the associative
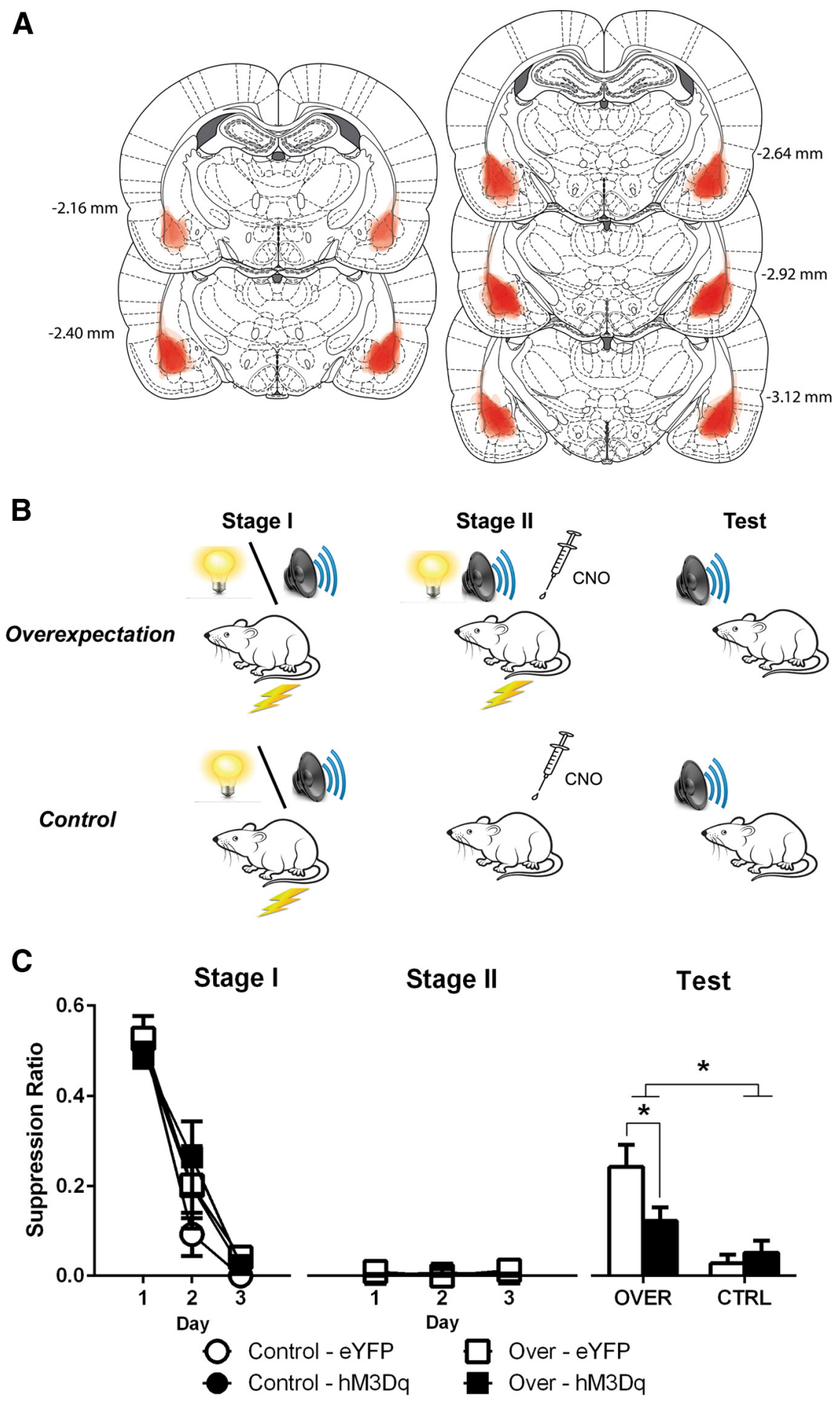

Figure 4. Chemogenetic activation of BLA glutamatergic neurons prevents use of negative prediction error to inhibit fear. $A$, Extent of eGFP-IR for each rat included in the analysis represented at $10 \%$ opacity. $B$, Behavioral procedure. All groups received CSA-shock and CSB-shock pairings in Stage I. In Stage II, Groups Over received CSA-shock presentations. Groups Control received further VI 120 training. CNO (3 mg/kg, i.p.) was injected $30 \mathrm{~min}$ before Stage II training. All groups were then tested for fear to CSA and CSB.C, Mean \pm SEM suppression ratios during Stage I, Stage II, and test. Overexpectation was attenuated in CaMKIII $\alpha-\mathrm{hM}_{3} \mathrm{D}_{\mathrm{q}}$ Over versus CaMKII $\alpha$-eYFP-Over. ${ }^{*} p<0.05$. Group sizes: CaMKII $\alpha$-hM3D - -0ver, $n=9$; CaMKII $\alpha$-eYFP-Over, $n=6$; CaMKIII $\alpha$ $\mathrm{hM}_{\mathrm{q}}$-Control, $n=6$; CaMKIII $\alpha$-eYFP-Control, $n=6$.

blocking experiment, the CNO-injected hM3Dq misplaced group showed normal behavioral function and learning.

Together, these findings argue strongly against nonselective or nonspecific effects of the hM3Dq or CNO manipulations on BLA function and fear learning. Instead, our findings indicate that 
chemogenetic excitation of BLA glutamatergic neurons has subtle and selective effects on fear learning.

\section{Heightened amygdala activation and disrupted prediction error}

Our data show that chemogenetic excitation of BLA glutamatergic neurons does not alter asymptotic levels of fear, increase the perceived intensity of the footshock, or augment fear memory consolidation because there were no within session or between session differences between hM3Dq and eYFP in acquisition or expression of simple forms of fear learning. This is consistent with observations that such simple fear learning is often unaltered in clinically anxious populations (Lissek et al., 2005) (but see below).

Rather, we detected a specific deficit in the use of prediction error to regulate fear learning. Prediction error regulates fear learning by matching increments and decrements in fear precisely to the danger posed. This error instructs fear learning to unexpected events (positive prediction error), prevents fear learning to expected events (no prediction error), and instructs inhibitory learning to omission of expected events (negative prediction error). hM3Dq excitation of BLA glutamatergic neurons disrupted use of this error to regulate fear learning. Specifically, this excitation yielded two consequences. First, it prevented associative blocking, causing inappropriate fear memory formation: animals learned to fear a CS that was not a valid predictor of danger in the associative blocking task. Animals in the Block$\mathrm{hM} 3 \mathrm{D}_{\mathrm{q}}$-CNO group showed significantly more fear to the blocked CS than the Block-hM3 $\mathrm{D}_{\mathrm{q}}$-Vehicle and Block-eYFP$\mathrm{CNO}$ controls. Second, chemogenetic excitation impaired fear inhibition. Animals were unable to use negative prediction error to reduce fear in the overexpectation task. Animals in the Over$\mathrm{hM} 3 \mathrm{D}_{\mathrm{q}}$ group showed impaired overexpectation compared with the Over-eYFP group. The finding of impaired inhibition of fear in overexpectation is important because, unlike fear extinction, which has multiple causes for fear loss (Rescorla, 2001; Myers and Davis, 2002), overexpectation selectively reveals actions of negative prediction error in causing fear loss.

Fear prediction error acts by regulating the activity of BLA neurons. Expected aversive events yield less recruitment of BLA and less fear learning than unexpected ones. This diminution of BLA activity during fear learning has been reported in rodents (Furlong et al., 2010; Johansen et al., 2010b) and humans (Dunsmoor et al., 2008; Eippert et al., 2012), including in human associative blocking tasks. It is due to periaqueductal gray-based circuits causing reductions in transmission of aversive US information to the BLA and reducing fear learning commensurately (Fanselow, 1998; McNally and Westbrook, 2006; McNally et al., 2011; Herry and Johansen, 2014). Chemogenetic excitation of BLA glutamatergic neurons may bypass circuit level feedback control over the activity of BLA glutamatergic neurons during fear learning. The hM3Dq excitation effectively circumvents control over BLA glutamatergic neuron activity by fear prediction error, enabling learning to a CS that is not a valid predictor of danger when it would not otherwise occur (blocking) and preventing fear inhibition (overexpectation). This insensitivity to prediction error during heightened BLA glutamatergic neuronal activation may provide a common mechanism for overgeneralization of fear and failures of fear inhibition characteristic of pathological anxiety (Jovanovic and Ressler, 2010; Dunsmoor and Paz, 2015).

\section{Amygdala and prediction error}

There are three additional features of these results that deserve comment. First, the effects of chemogenetic excitation in the overexpectation design could suggest that BLA glutamatergic neurons show bidirectional sensitivity to prediction error: positive error and increments in fear are coded by increases in activity, whereas negative error and decrements in fear are coded by decreases in activity. However, it is equally plausible that such errors are coded by excitation in distinct populations of BLA glutamatergic neurons (e.g., fear "on" and "off" cells) (Herry et al., 2008; Senn et al., 2014). The chemogenetic BLA manipulation does not allow easy distinction between these possibilities. Second, BLA lesions do not affect prediction error driven upregulation of attention to CS in Pavlovian appetitive conditioning (Holland et al., 2001). This suggests that BLA contributions to the effects of prediction error may differ in appetitive and fear conditioning, a suggestion supported by the role of nucleus accumbens in attentional selection of danger signals ( $\mathrm{Li}$ and McNally, 2015). Finally, the deficit in use of prediction error was restricted to the blocking and overexpectation designs. There was no effect on simple fear acquisition. BLA glutamatergic neurons may be especially sensitive to fear learning based on pooled or summed prediction errors (e.g., during blocking and overexpectation) and less sensitive to learning based on unique or individual errors (e.g., during single cue conditioning) (Le Pelley, 2004). However, given that manipulations of BLA glutamatergic neurons affect learning to individual cues (Wolff et al., 2014), this is an interesting but unlikely possibility. Alternatively, despite sensitivity to differences in asymptotic levels of fear learning, our measure may have been less sensitive to differences in rate of learning. This could obscure any effect on the DREADD manipulation on fear learning to the single cues. Indeed, DREADDs modulate fear acquisition in mice using immobility as the measure of learned fear (Yiu et al., 2014).

In conclusion, here we combined chemogenetic techniques with behavioral approaches isolating the actions of fear prediction error to show that heightened activation of BLA glutamatergic neurons acts selectively to disrupt use of prediction error in regulating fear learning. Animals were less able to use their past experience with danger to regulate their future learning about this danger, as shown by impaired associative blocking, and were less able to reduce fear when fear expectations exceeded the danger posed, as shown by impaired overexpectation. Chemogenetic excitation of BLA glutamatergic neurons could therefore serve as a useful model for identifying the cellular and circuit level consequences of heightened amygdala activation as well as for understanding fear prediction error signals in pathological anxiety.

\section{References}

Alexander GM, Rogan SC, Abbas AI, Armbruster BN, Pei Y, Allen JA, Nonneman RJ, Hartmann J, Moy SS, Nicolelis MA, McNamara JO, Roth BL (2009) Remote control of neuronal activity in transgenic mice expressing evolved G-protein coupled receptors. Neuron 63:27-39. CrossRef Medline

Annau Z, Kamin LJ (1961) The conditioned emotional response as a function of the intensity of the US. J Comp Physiol Psychol 54:428-432. CrossRef Medline

Arico C, McNally GP (2014) Opioid receptors regulate blocking and overexpectation of fear learning in conditioned suppression. Behav Neurosci 128:199-206. CrossRef Medline

Armbruster BN, Li X, Pausch MH, Herlitze S, Roth BL (2007) Evolving the lock to fit the key to create a family of $G$ protein-coupled receptors potently activated by an inert ligand. Proc Natl Acad Sci U S A 104:51635168. CrossRef Medline

Bell LA, Bell KA, McQuiston AR (2013) Synaptic muscarinic response types 
in hippocampal CA1 interneurons depend on different levels of presynaptic activity and different muscarinic receptor subtypes. Neuropharmacology 73:160-173. CrossRef Medline

Davis M (1992) The role of the amygdala in fear and anxiety. Annu Rev Neurosci 15:353-375. CrossRef Medline

Desmedt A, Marighetto A, Piazza PV (2015) Abnormal fear memory as a model for posttraumatic stress disorder. Biol Psychiatry 78:290-297. CrossRef Medline

Dunsmoor JE, Paz R (2015) Fear generalization and anxiety: behavioral and neural mechanisms. Biol Psychiatry 78:336-343. CrossRef Medline

Dunsmoor JE, Bandettini PA, Knight DC (2008) Neural correlates of unconditioned response diminution during Pavlovian conditioning. Neuroimage 40:811-817. CrossRef Medline

Ehrlich I, Humeau Y, Grenier F, Ciocchi S, Herry C, Lüthi A (2009) Amygdala inhibitory circuits and the control of fear memory. Neuron 62:757-771. CrossRef Medline

Eippert F, Gamer M, Büchel C (2012) Neurobiological mechanisms underlying the blocking effect in aversive learning. J Neurosci 32:13164-13176. CrossRef Medline

Fanselow MS (1998) Pavlovian conditioning, negative feedback, and blocking: mechanisms that regulate association formation. Neuron 20: 625-627. CrossRef Medline

Farb CR, Ledoux JE (1999) Afferents from rat temporal cortex synapse on lateral amygdala neurons that express NMDA and AMPA receptors. Synapse 33:218-229. CrossRef Medline

Furlong TM, Cole S, Hamlin AS, McNally GP (2010) The role of prefrontal cortex in predictive fear learning. Behav Neurosci 124:574-586. CrossRef Medline

Goossens L, Sunaert S, Peeters R, Griez EJ, Schruers KR (2007) Amygdala hyperfunction in phobic fear normalizes after exposure. Biol Psychiatry 62:1119-1125. CrossRef Medline

Guthrie RM, Bryant RA (2006) Extinction learning before trauma and subsequent posttraumatic stress. Psychosom Med 68:307-311. CrossRef Medline

Harris RJ (2004) ANOVA: an analysis of variance primer. Itasca, IL: Peacock.

Herry C, Johansen JP (2014) Encoding of fear learning and memory in distributed neuronal circuits. Nat Neurosci 17:1644-1654. CrossRef Medline

Herry C, Ciocchi S, Senn V, Demmou L, Müller C, Lüthi A (2008) Switching on and off fear by distinct neuronal circuits. Nature 454:600-606. CrossRef Medline

Holland PC, Hatfield T, Gallagher M (2001) Rats with basolateral amygdala lesions show normal increases in conditioned stimulus processing but reduced conditioned potentiation of eating. Behav Neurosci 115: 945-950. CrossRef Medline

Johansen JP, Hamanaka H, Monfils MH, Behnia R, Deisseroth K, Blair HT, LeDoux JE (2010a) Optical activation of lateral amygdala pyramidal cells instructs associative fear learning. Proc Natl Acad Sci U S A 107: 12692-12967. CrossRef Medline

Johansen JP, Tarpley JW, LeDoux JE, Blair HT (2010b) Neural substrates for expectation-modulated fear learning in the amygdala and periaqueductal gray. Nat Neurosci 13:979-986. CrossRef Medline

Jovanovic T, Ressler KJ (2010) How the neurocircuitry and genetics of fear inhibition may inform our understanding of PTSD. Am J Psychiatry 167: 648-662. CrossRef Medline

Jovanovic T, Norrholm SD, Blanding NQ, Davis M, Duncan E, Bradley B, Ressler KJ (2010) Impaired fear inhibition is a biomarker of PTSD but not depression. Depress Anxiety 27:244-251. CrossRef Medline

Jovanovic T, Kazama A, Bachevalier J, Davis M (2012) Impaired safety signal learning may be a biomarker of PTSD. Neuropharmacology 62: 695-704. CrossRef Medline

Kamin LJ (1968) Attention-like processes in classical conditioning. In: Miami symposium on the prediction of behavior: aversive stimulation (Campbell BJ, Church RM, eds), pp 9-33. Miami: University of Miami.

Lanuza E, Moncho-Bogani J, Ledoux JE (2008) Unconditioned stimulus pathways to the amygdala: effects of lesions of the posterior intralaminar thalamus on foot-shock-induced c-Fos expression in the subdivisions of the lateral amygdala. Neuroscience 155:959-968. CrossRef Medline

Lattal KM, Nakajima S (1998) Overexpectation in appetitive Pavlovian and instrumental conditioning. Anim Learn Behav 26:351-360. CrossRef

Le Pelley ME (2004) The role of associative history in models of associative learning: a selective review and a hybrid model. Q J Exp Psychol 57: 193-243. CrossRef Medline

Li SS, McNally GP (2015) Selecting danger signals: dissociable roles of nucleus accumbens shell and core glutamate in predictive fear learning. Eur J Neurosci 41:1515-1523. CrossRef Medline

Lissek S, Powers AS, McClure EB, Phelps EA, Woldehawariat G, Grillon C, Pine DS (2005) Classical fear conditioning in the anxiety disorders: a meta-analysis. Behav Res Ther 43:1391-1424. CrossRef Medline

Lüthi A, Lüscher C (2014) Pathological circuit function underlying addiction and anxiety disorders. Nat Neurosci 17:1635-1643. CrossRef Medline

Marek R, Strobel C, Bredy TW, Sah P (2013) The amygdala and medial prefrontal cortex: partners in the fear circuit. J Physiol 591:2381-2391. CrossRef Medline

Maren S, Quirk GJ (2004) Neuronal signalling of fear memory. Nat Rev Neurosci 5:844-852. CrossRef Medline

McKernan MG, Shinnick-Gallagher P (1997) Fear conditioning induces a lasting potentiation of synaptic currents in vitro. Nature 390:607-611. CrossRef Medline

McNally GP, Westbrook RF (2006) Predicting danger: the nature, consequences, and neural mechanisms of predictive fear learning. Learn Mem 13:245-253. CrossRef Medline

McNally GP, Pigg M, Weidemann G (2004) Blocking, unblocking, and overexpectation of fear: a role for opioid receptors in the regulation of Pavlovian association formation. Behav Neurosci 118:111-120. CrossRef Medline

McNally GP, Johansen JP, Blair HT (2011) Placing prediction into the fear circuit. Trends Neurosci 34:283-292. CrossRef Medline

McQuiston AR, Madison DV (1999) Muscarinic receptor activity has multiple effects on the resting membrane potentials of CA1 hippocampal interneurons. J Neurosci 19:5693-5702. Medline

Michael T, Blechert J, Vriends N, Margraf J, Wilhelm FH (2007) Fear conditioning in panic disorder: enhanced resistance to extinction. J Abnorm Psychol 116:612-617. CrossRef Medline

Myers KM, Davis M (2002) Behavioral and neural analysis of extinction. Neuron 36:567-584. CrossRef Medline

Paré D, Quirk GJ, Ledoux JE (2004) New vistas on amygdala networks in conditioned fear. J Neurophysiol 92:1-9. CrossRef Medline

Paxinos G, Watson C (2007) The rat brain in stereotaxic coordinates, Ed 6 . Amsterdam: Elsevier.

Rachman S (1994) The overprediction of fear: a review. Behav Res Ther 32:683-690. CrossRef Medline

Rauch SL, Shin LM, Phelps EA (2006) Neurocircuitry models of posttraumatic stress disorder and extinction: human neuroimaging researchpast, present, and future. Biol Psychiatry 60:376-382. CrossRef Medline

Rescorla RA (1970) Reduction in the effectiveness of reinforcement after prior excitatory conditioning. Learn Motivation 1:372-381. CrossRef

Rescorla RA (2001) Experimental extinction. In: Handbook of contemporary learning theories (Klein SB, Mowrer, eds), pp 119-154. Hillsdale, NJ: Erlbaum.

Rescorla RA (2007) Renewal after overexpectation. Learn Behav 35:19-26. CrossRef Medline

Rescorla RA, Wagner AR (1972) A theory of Pavlovian conditioning: variations in the effectiveness of reinforcement and nonreinforcement. In: Classical conditioning II: current research and theory (Black AH, Prokasy WF, eds), pp 64-99. New York: Appleton-Century Crofts.

Rogan SC, Roth BL (2011) Remote control of neuronal signaling. Pharmacol Rev 63:291-315. CrossRef Medline

Sah P, Faber ES, Lopez De Armentia M, Power J (2003) The amygdaloid complex: anatomy and physiology. Physiol Rev 83:803-834. CrossRef Medline

Schafe GE, Nader K, Blair HT, LeDoux JE (2001) Memory consolidation of Pavlovian fear conditioning: a cellular and molecular perspective. Trends Neurosci 24:540-546. CrossRef Medline

Senn V, Wolff SB, Herry C, Grenier F, Ehrlich I, Gründemann J, Fadok JP, Müller C, Letzkus JJ, Lüthi A (2014) Long-range connectivity defines behavioral specificity of amygdala neurons. Neuron 81:428-437. CrossRef Medline

Shi C, Davis M (1999) Pain pathways involved in fear conditioning measured with fear-potentiated startle: lesion studies. J Neurosci 19:420-430. Medline 
Shin LM, Liberzon I (2010) The neurocircuitry of fear, stress, and anxiety disorders. Neuropsychopharmacology 35:169-191. CrossRef Medline

Shin LM, Kosslyn SM, McNally RJ, Alpert NM, Thompson WL, Rauch SL, Macklin ML, Pitman RK (1997) Visual imagery and perception in posttraumatic stress disorder. Arch Gen Psychiatry 54:233-241. CrossRef Medline

Shin LM, Wright CI, Cannistraro PA, Wedig MM, McMullin K, Martis B, Macklin ML, Lasko NB, Cavanagh SR, Krangel TS, Orr SP, Pitman RK, Whalen PJ, Rauch SL (2005) A functional magnetic resonance imaging study of amygdala and medial prefrontal cortex responses to overtly presented fearful faces in posttraumatic stress disorder. Arch Gen Psychiatry 62:273-281. CrossRef Medline

Sternson SM, Roth BL (2014) Chemogenetic tools to interrogate brain functions. Annu Rev Neurosci 37:387-407. CrossRef Medline

Storsve AB, McNally GP, Richardson R (2010) US habituation, like CS extinction, produces a decrement in conditioned fear responding that is NMDA dependent and subject to renewal and reinstatement. Neurobiol Learn Mem 93:463-471. CrossRef Medline

Storsve AB, McNally GP, Richardson R (2012) Renewal and reinstatement of the conditioned but not the unconditioned response following habituation of the unconditioned stimulus. Behav Processes 90:58-65. CrossRef Medline

Tillfors M, Furmark T, Marteinsdottir I, Fischer H, Pissiota A, Långström B, Fredrikson M (2001) Cerebral blood flow in subjects with social phobia during stressful speaking tasks: a PET study. Am J Psychiatry 158: 1220-1226. CrossRef Medline
Tillfors M, Furmark T, Marteinsdottir I, Fredrikson M (2002) Cerebral blood flow during anticipation of public speaking in social phobia: a PET study. Biol Psychiatry 52:1113-1119. CrossRef Medline

Tovote P, Fadok JP, Lüthi A (2015) Neuronal circuits for fear and anxiety. Nat Rev Neurosci 16:317-331. CrossRef Medline

Urban DJ, Roth BL (2013) DREADDs (designer receptors exclusively activated by designer drugs): chemogenetic tools with therapeutic utility. Annu Rev Pharmacol Toxicol 55:399-417. CrossRef Medline

Wolff SB, Gründemann J, Tovote P, Krabbe S, Jacobson GA, Müller C, Herry C, Ehrlich I, Friedrich RW, Letzkus JJ, Lüthi A (2014) Amygdala interneuron subtypes control fear learning through disinhibition. Nature 509:453-458. CrossRef Medline

Yau JO, McNally GP (2015) Pharmacogenetic excitation of dorsomedial prefrontal cortex restores fear prediction error. J Neurosci 35:74-83. CrossRef Medline

Yiu AP, Mercaldo V, Yan C, Richards B, Rashid AJ, Hsiang HL, Pressey J, Mahadevan V, Tran MM, Kushner SA, Woodin MA, Frankland PW, Josselyn SA (2014) Neurons are recruited to a memory trace based on relative neuronal excitability immediately before training. Neuron 83 : 722-735. CrossRef Medline

Zhao S, Ting JT, Atallah HE, Qiu L, Tan J, Gloss B, Augustine GJ, Deisseroth K, Luo M, Graybiel AM, Feng G (2011) Cell type-specific channelrhodopsin-2 transgenic mice for optogenetic dissection of neural circuitry function. Nat Methods 8:745-752. CrossRef Medline 